\title{
PENGEMBANGAN PERANGKAT PEMBELAJARAN MATEMATIKA BERBASIS MASALAH PADA POKOK BAHASAN PERSAMAAN LINEAR DUA VARIABEL
}

\author{
Syamsir ${ }^{1}$, Andi Halimah ${ }^{2}$, Andi Ika Prasasti Abrar ${ }^{3}$ \\ 1,2,3Universitas Islam Negeri Alauddin Makassar \\ Kampus II: Jl. H.M. Yasin Limpo No. 36 Samata-Gowa \\ Email: syamsirger88@gmail.com¹, andi.halimah@uin-alauddin.ac.id², \\ andi.ikaprasasti@uin-alauddin.ac.id ${ }^{3}$
}

\begin{abstract}
Abstrak:
Penelitian ini membahas tentang pengembangan perangkat pembelajaran matematika berbasis masalah pada pokok bahasan persamaan linear dua variabel. Penelitian ini bertujuan menghasilkan perangkat pembelajaran matematika berbasis masalah pada pokok bahasan persamaan linear dua variabel kelas VIII MTsN 1 Makassar yang valid, praktis dan efektif. Jenis penelitian ini adalah penelitian pengembangan (research and development) yaitu pengembangan perangkat pembelajaran yang terdiri atas: Rencana Pelaksanaan Pembelajaran, Buku Peserta didik, Lembar Kerja Peserta Didik, dan Tes Hasil Belajar. Model pengembangan perangkat yang digunakan dalam penelitian ini adalah model pembelajaran berbasis masalah dan mengacu pada model Plomp yang terdiri dari tahapan pengkajian awal (preliminary investigation), perancangan (design), realisasi/kontruksi (realization/ construction), tes, evaluasi, dan revisi (test, evaluation, and revision), dan implementasi (implementation). Pada penelitian ini dilakukan secara terbatas di kelas VIII MTsN 1 Makassar. Kualitas kevalidan perangkat pembelajaran memenuhi kriteria valid berdasarkan penilaian validator, sedangkan hasil yang diperoleh pada uji coba terbatas yaitu: pertama, perangkat pembelajaran sudah praktis, tetapi masih ada beberapa saran pengamat yang perlu diperhatikan untuk meningkatkan kepraktisan perangkat, kedua, perangkat pembelajaran sudah efektif, karena ketuntasan hasil belajar telah tercapai dan aktivitas peserta didik sudah sesuai yang diharapkan, kemampuan guru mengelola pembelajaran sudah dalam kategori tinggi dan respons peserta didik sudah dalam kategori positif.
\end{abstract}

\begin{abstract}
:
This research discussed about the development of problem-based mathematics learning tools on the subject of two linear equations. This research aimed to produce a valid, practical, and effective problem-based mathematics learning tools on the subject of linear equations of two variables of class VIII MTsN 1 Makassar. The type of this research was research and development, which is development of learning tools consist of lesson plan,
\end{abstract}


text book, student work sheet, and learning test. This research used problembased learning as a device of development model and the Plomp model consisting of preliminary investigation, design, realization/construction, evaluation and revision, and implementation. This research conducted in a limited class VIII MTsN 1 Makassar. Valid quality and learning tools fulfilled valid criteria based on assesment by two validators. While results obtained in the limited trial are: (1) learning tools are practical, but there were still some observers' suggestions need to be considered to improve the practicality of device, (2) learning tools have been effective because the master criterion of learning has been achieved, student activity were as expected, the ability of teachers to manage the learning has achievedi the high category and students' response were in the positive category.

Kata kunci: Perangkat Pembelajaran, Pembelajaran Berbasis Masalah

PENDIDIKAN merupakan salah satu tolok ukur terhadap tingkat peradaban dan kemajuan suatu negara. Pendidikan dijadikan komponen penyusun Human Development Index (HDI) atau Indeks Pembangunan Manusia (IPM) yang merupakan salah satu indikator kemajuan pembangunan suatu negara. Pendidikan dapat dipandang dalam arti luas dan arti teknis. Pendidikan dalam arti luas mengacu pada suatu tindakan atau pengalaman yang mempunyai pengaruh yang berhubungan dengan pertumbuhan atau perkembangan jiwa (mind), watak (character), dan kemampuan fisik (physical ability). Pendidikan dalam arti teknis artinya pendidikan adalah proses dimana masyarakat melalui lembaga-lembaga pendidikan (sekolah, perguruan tinggi, atau lembaga-lembaga lain) dengan sengaja mentransformasikan warisan budaya, yaitu pengetahuan, nilai, keterampilan dari generasi ke generasi. Hal ini menunjukkan bahwa keberadaan pendidikan sangatlah penting (Siswono, 2008:17).

Pada umumnya, pendidikan nasional berfungsi mengembangkan kemampuan dan membentuk watak serta peradaban bangsa yang bermartabat dalam rangka mencerdaskan kehidupan bangsa. Hal ini bertujuan untuk mengembangkan potensi peserta didik agar menjadi manusia yang beriman dan bertakwa kepada Tuhan Yang Maha Esa, berakhlak mulia, sehat, berilmu, cakap, kreatif, mandiri, dan menjadi warga negara demokrasi yang bertanggung jawab (UU Sistem Pendidikan Nasional, 2011:7).

Untuk mencapai tujuan pendidikan nasionaltersebut, perhatian pemerintah terhadap dunia pendidikan saat ini dirasakan sudah cukup baik. Terbukti dengan dikeluarkannya kurikulum pendidikan yang terbaru yaitu Kurikulum 2013. Dimana kompetensi inti yang tercantum di dalamnya terdiri dari empat poin, yakni sikap moral, sikap sosial, pengetahuan dan keterampilan. Kurikulum ini memang belum diterapkan sepenuhnya disemua sekolah, namun kurikulum ini masih terus dikembangkan dan dibenahi. 
Kemajuan ilmu pengetahuan dan teknologi (IPTEK) telah mendorong setiap negara terutama negara-negara yang sedang berkembang, termasuk negara republik Indonosia yang dicintai ini untuk senantiasa mengembangkan sistem pendidikan nasionalnya agar dapat menyesuaikan diri dengan perkembangan zaman yang semakin hari semakin maju dan mampu melahirkan manusia-manusia yang berkulitas yang dapat bersaing diera globalisasi seperti sekarang ini.

Salah satu masalah yang dihadapi dunia pendidikan adalah lemahnya proses pembelajaran yang berimplikasi pada hasil belajar peserta didik. Dalam proses pembelajaran, peserta didik kurang didorong untuk mengembangkan kemampuan berpikir sehingga peserta didik cenderung pasif dalam proses pembelajaran.

Menurut Muchlis dalam (Nurhidayati, Tayeb, \& Abbas, 2017: 7), banyak peserta didik yang hanya menghafal materi pelajaran matematika, tetapi tidak mampu mengaplikasikan ilmunya dalam kehidupan sehari-hari. Kondisi ini berdampak terhadap pemahaman peserta didik yang rendah akan konsep-konsep dalam mata pelajaran matematika. Padahal, pemahaman konsep merupakan bagian penting dalam kurikulum 2013 yang dituangkan dalam tujuan mata pelajaran yang diberikan di SMP yakni peserta didik memiliki kemampuan dalam memahami konsep matematika.

Sehubungan dengan hal tersebut, dari hasil observasi yang telah dilakukan di MTsN 1 Makassar dengan wawancara terhadap guru dan peserta didik didapatkan data bahwa kemampuan peserta didik dalam memecahkan soal-soal matematika salah satunya kemampuan dalam menyelesaikan soal-soal cerita yang masih rendah. Banyak peserta didik yang masih belum mampu memahami maksud dari soal cerita dan mengubah soal cerita tersebut dalam bentuk model matematika. Peserta didik belum mampu menarik kesimpulan dari suatu permasalahan (soal cerita). Selain itu, 20 orang peserta didik hanya menghafal rumus untuk menyelesaikan soal. Dalam menyelesaikan soal-soal dengan menggunakan banyak rumus kebanyakan peserta didik belum mampu menyelesaikan dengan baik. Salah satu materi yang dianggap sulit oleh peserta didik adalah materi sistem persamaan linear dua variabel karena dianggap abstrak oleh peserta didik. Beberapa peserta didik juga cenderung tidak menyukai mata pelajaran matematika. Hal ini terjadi karena peserta didik menganggap matematika sebagai pelajaran yang sulit karena mempunyai banyak rumus. Hal tersebut, mengindikasikan bahwa kemampuan penalaran matematis peserta didik masih tergolong rendah.

Oleh karena itu, kegiatan kolaborasi antara guru, peserta didik, dan dosen untuk mengonstruksi komponen-komponen pembelajaran matematika yang berpotensi untuk menumbuhkembangkan kemampuan penalaran peserta didik SMP perlu dilakukan.

Salah satu pembelajaran yang dapat menumbuhkembangkan kemampuan penalaran peserta didik, yakni pembelajaran berbasis masalah (Insani, Suharto, \& Indah, 2014). Pembelajaran berbasis masalah merupakan pembelajaran yang memusatkan perhatian kepada peserta didik dan diharapkan hal ini dilakukan oleh 
para guru matematika di sekolah untuk mencapai kompetensi matematis (Tatang, 2007: 55). Pengajaran berdasarkan masalah efektif untuk pengajaran proses berpikir tingkat tinggi. Pembelajaran ini membantu peserta didik dalam memproses informasi yang sudah jadi dalam benaknya dan menyusun pengetahuan mereka sendiri tentang dunia sosial dan sekitarnya. Pembelajaran ini cocok diterapkan untuk mengembangkan pengetahuan dasar maupun pengetahuan kompleks peserta didik. Karakteristik pembelajaran berbasis masalah adalah sebagai berikut:

a. Permasalahan menjadi starting point dalam belajar;

b. Permasalahan yang diangkat adalah permasalahan yang ada di dunia nyata yang tidak terstruktur;

c. Permasalahan membutuhkan perspektif ganda (multiple perspective);

d. Permasalahan, menantang pengetahuan yang dimiliki oleh peserta didik, sikap, dan kompetensi yang kemudian membutuhkan identifikasi kebutuhan belajar dan bidang baru dalam belajar;

e. Belajar pengarahan diri menjadi hal yang utama;

f. Pemanfaatan sumber pengetahuan yang beragam, penggunaannya, dan evaluasi sumber informasi merupakan proses yang esensial dalam PBM;

g. Belajar adalah kolaboratif, komunikasi, dan kooperatif;

h. Pengembangan keterampilan inquiry dan pemecahan masalah sama pentingnya dengan penguasaan isi pengetahuan untuk mencari solusi dari sebuah permasalahan;

i. Keterbukaan proses dalam PBM meliputi sintesis dan integrasi dari sebuah proses belajar; dan

j. PBM melibatkan evaluasi dan review pengalaman peserta didik dan proses belajar;

Pembelajaran berdasarkan masalah memiliki tujuan: membantu peserta didik mengembangkan keterampilan berpikir dan keterampilan pemecahan masalah, belajar peranan orang dewasa yang autentik, dan menjadi pembelajar yang mandiri.

Manfaat pengajaran berdasarkan masalah adalah pengajaran berdasarkan masalah tidak dirancang untuk membantu guru memberikan informasi sebanyakbanyaknya kepada peserta didik. Pengajaran berdasarkan masalah dikembangkan untuk membantu peserta didik mengembangkan kemampuan berpikir, pemecahan masalah, dan keterampilan intelektual, belajar berbagai peran orang dewasa melalui pelibatan mereka dalam pengalaman nyata atau simulasi, dan menjadi pembelajar yang otonom dan mandiri.

Pengajaran berdasarkan masalah terdiri dari 5 langkah utama yang dimulai dengan guru memperkenalkan peserta didik dengan suatu masalah dan diakhiri dengan penyajian dan analisis hasil kerja peserta didik (Abrar, 2016). Kelima langkah tersebut dijelaskan berdasarkan langkah-langkah pada tabel 1. 
Tabel 1. Sintaks Pembelajaran Berbasis Masalah

\begin{tabular}{|c|c|}
\hline Tahap & Aktivitas Guru \\
\hline $\begin{array}{l}\text { Tahap-1 } \\
\text { Orientasi peserta didik } \\
\text { pada masalah }\end{array}$ & $\begin{array}{l}\text { Guru menjelaskan tujuan } \\
\text { pembelajaran, menjelaskan logistik } \\
\text { yang dibutuhkan, mengajukan } \\
\text { fenomena atau demonstrasi atau cerita } \\
\text { untuk memunculkan masalah, } \\
\text { memotivasi peserta didik untuk } \\
\text { terlibat dalam pemecahan masalah } \\
\text { yang dipilih. }\end{array}$ \\
\hline $\begin{array}{l}\text { Tahap-2 } \\
\text { Mengorganisasi peserta } \\
\text { didik untuk belajar }\end{array}$ & $\begin{array}{l}\text { Guru membantu peserta didik umtuk } \\
\text { mendefinisikan dan } \\
\text { mengorganisasikan tugas belajar yang } \\
\text { berhubungan dengan masalah } \\
\text { tersebut. }\end{array}$ \\
\hline $\begin{array}{l}\text { Tahap-3 } \\
\text { Membimbing } \\
\text { penyelidikan individual } \\
\text { maupun kelompok }\end{array}$ & $\begin{array}{l}\text { Guru mendorong peserta didik untuk } \\
\text { mengumpulkan informasi yang sesuai, } \\
\text { melaksanakan eksperimen, untuk } \\
\text { mendapatkan penjelasan dan } \\
\text { pemecahan masalah. }\end{array}$ \\
\hline $\begin{array}{l}\text { Tahap- } 4 \\
\text { Mengembangkan dan } \\
\text { menyajikan hasil karya }\end{array}$ & $\begin{array}{l}\text { Guru membantu peserta didik dalam } \\
\text { merencanakan dan menyiapkan karya } \\
\text { yang sesuai seperti laporan, video, dan } \\
\text { model serta membantu mereka untuk } \\
\text { berbagi tugas dengan temannya. }\end{array}$ \\
\hline $\begin{array}{l}\text { Tahap- } 5 \\
\text { Menganalisis dan } \\
\text { mengevaluasi proses } \\
\text { pemecahan masalah }\end{array}$ & $\begin{array}{l}\text { Guru membantu peserta didik untuk } \\
\text { melakukan refleksi atau evaluasi } \\
\text { terhadap penyelidikan mereka dan } \\
\text { proses-proses yang mereka gunakan. }\end{array}$ \\
\hline
\end{tabular}

Oleh karena itu, peneliti ingin mengembangkan perangkat pembelajaran matematika berbasis masalah dengan mengambil topik sistem persamaan linear dua variable yang bertujuan untuk menghasilkan perangkat pembelajaran yang valid, praktis, dan efektif.

\section{METODE PENELITIAN}

Penelitian ini merupakan penelitian pengembangan (research and development) yaitu pengembangan perangkat pembelajaran yang terdiri atas: Rencana Pelaksanaan Pembelajaran (RPP), Buku Siswa (BS), Lembar Kerja Peserta Didik (LKPD), dan Tes Hasil Belajar (THB). Research and development adalah kerja kreatif yang dilakukan secara sistematis untuk menambah khasanah pengetahuan dan memanfaatkannya 
untuk merancang berbagai aplikasi (Munawarah, 2017: 172). Menurut (Sugiyono, 2012.:407) penelitian pengembangan adalah metode penelitian yang digunakan untuk menghasilkan produk tertentu dan menguji keefektifan produk tersebut. Jadi dapat disimpulkan bahwa pengembangan perangkat pembelajaran adalah serangkaian proses atau kegiatan yang dilakukan untuk menghasilkan suatu perangkat pembelajaran berdasarkan teori yang telah ada. Tujuannya adalah untuk mengembangjan dan mendapatkan prototipe produk dan perumusan saran-saran metodologis untuk pendesainan dan evaluasi prototipe tersebut. Perangkat pembelajaran akan mempengaruhi keberhasilan proses pembelajaran di kelas, karena memberikan kemudahan dan mampu membantu guru dalam mempersiapkan dan melaksanakan kegiatan belajar mengajar. Oleh sebab itu, perangkat pembelajaran mutlak diperlukan oleh seorang guru dalam mengelola pembelajaran.

Subjek coba dalam penelitian ini adalah peserta didik kelas VIII MTsN 1 Makassar. Instrumen pengumpulan data yang digunakan dalam penelitian ini adalah (1) lembar validasi ahli untuk mengukur kevalidan produk (2) lembar observasi keterlaksanaan perangkat pembelajaran untuk mengukur kepraktisan produk dan (3) lembar observasi kemampan guru mengelola pembelajaran, angket respons peserta didik, lembar observasi aktivitas peserta didik dan tes hasil belajar (THB) untuk mengukur keefektifan produk. Data yang dikumpulkan dengan menggunakan instrumen-instrumen tersebut, selanjutnya dianalisis secara komutatif dan diarahkan untuk menjelaskan kevalidan, keefektifan dan kepraktisan perangkat pembelajaran matematika berbasis masalah. Adapun data hasil uji coba di kelas digunakan untuk menjelaskan keefektifan dan kepraktisan perangkat pembelajaran matematika berbasis masalah. Berikut ini dikemukakan tentang analisis data kevalidan, kepraktisan dan keefektifan.

Tabel 2. Analisis Data Kevalidan, Kepraktisan dan Keefektifan

\begin{tabular}{|c|c|c|c|c|c|}
\hline \multicolumn{2}{|r|}{ Kevalidan } & Praktis & \multicolumn{3}{|c|}{ Efektif } \\
\hline 1) & $\begin{array}{c}\text { Mencari rerata hasil } \\
\text { penilaian dari semua } \\
\text { validator untuk setiap } \\
\text { kriteria dengan rumus: } \\
\overline{\boldsymbol{K} \boldsymbol{\imath}}=\frac{\sum_{j=1}^{n} \boldsymbol{V}_{i j}}{\boldsymbol{n}} \text {, dengan : } \\
\overline{\boldsymbol{K} \boldsymbol{\imath}}=\text { rata-rata kriteria } \\
\text { ke-i } \\
\boldsymbol{V}_{\boldsymbol{i j}}=\text { skor hasil } \\
\text { penilaian } \\
\text { terhadap kriteria } \\
\text { ke-I oleh penilai } \\
\text { ke-j } \\
\boldsymbol{n}=\text { jumlah penilai } \\
\text { (Validator) }\end{array}$ & \begin{tabular}{lr} 
Data & kepraktisan \\
perangkat & pembelajaran \\
berbasis masalah & \multicolumn{2}{r}{ mata } \\
diperoleh & melalui data \\
dari & pengamatan \\
keterlaksanaan \\
perangkat pembelajaran \\
berbasis masalah secara \\
umum. Pada analisis \\
data keterlaksanaan \\
perangkat pembelajaran \\
berbasis masalah, kriteria \\
yang digunakan untuk \\
memutuskan bahwa
\end{tabular} & 1) & $\begin{array}{l}\text { Tes } \\
\text { den } \\
K B \\
\text { Ket } \\
\text { KB }\end{array}$ & $\begin{array}{l}\text { lasil belajar } \\
=\frac{T}{T_{1}} \times 100 \% \\
\text { rangan : } \\
\text { = Ketuntasan } \\
\text { Belajar } \\
=\text { Jumlah } \\
\text { skor yang } \\
\text { diperoleh } \\
\text { peserta didik } \\
=\text { Jumlah } \\
\text { skor total } \\
\text { ket respons } \\
\text { rta didik }\end{array}$ \\
\hline
\end{tabular}




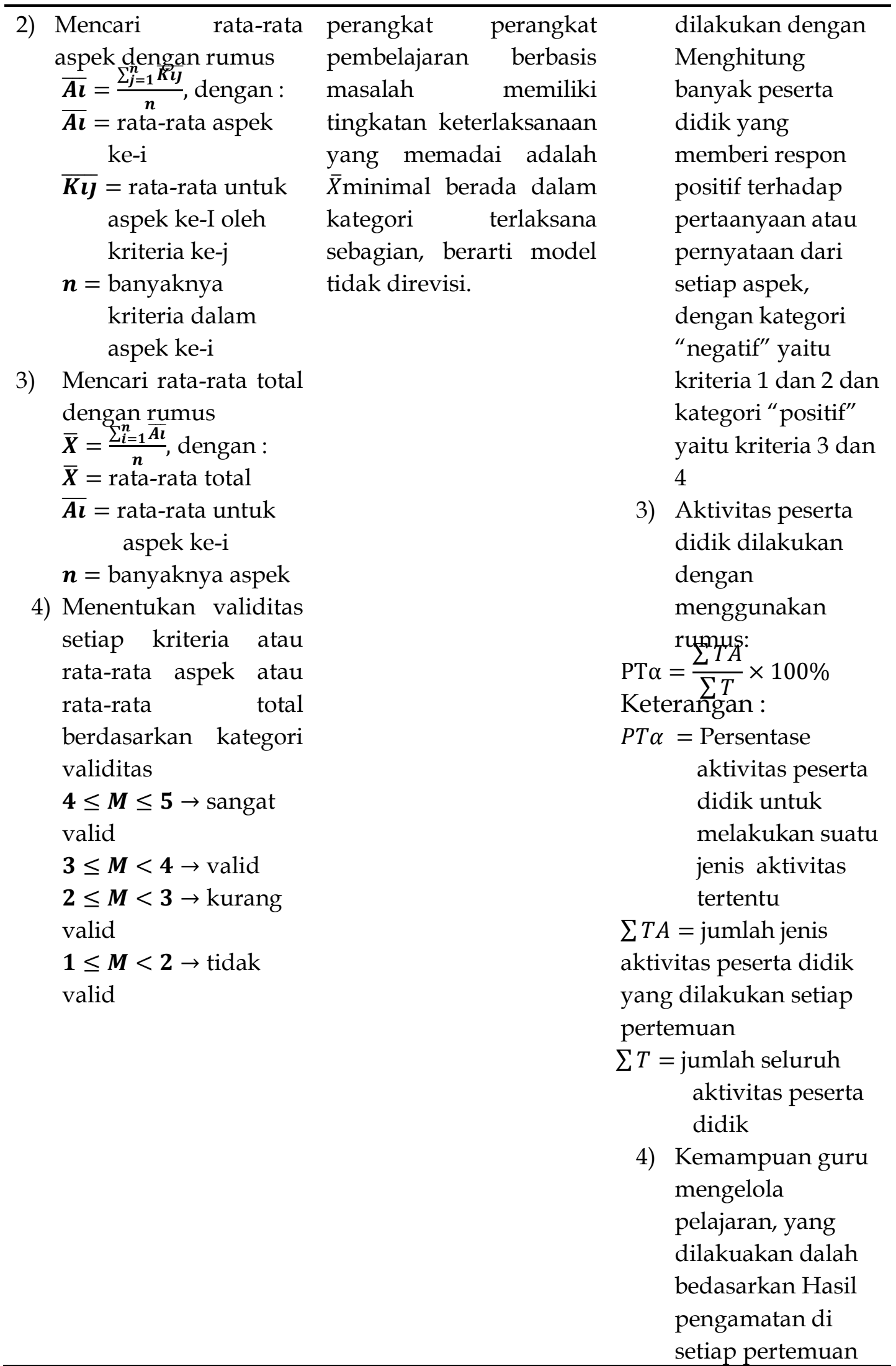




direkap sehingga
terkumpul semua
skor setiap kriteria
pengamatan
pengelolaan
pembelajaran dan
kemudian dihitung
rata-ratanya.
Langkah
berikutnya adalah
menentukan rata-
rata tiap-tiap fase
kegiatan
pembelajaran
berdasarkan rata-
rata setiap
pengamatan yang
dihitung
sebelumnya.
Akhirnya
berdasarkan rata-
rata penilaian
semua fase
pengelolaan
pembelajaran di
tentukan nilai rata-
rata total
pengelolaan
pembelajaran
untuk kemudian di
tentukan
kemampuan guru
mengelola
pembelajaran
dengan kriteria

\section{HASIL DAN PEMBAHASAN}

Berikut ini hasil yang diperoleh dari penelitian pengembangan perangkat pembelajaran matematika berbasis masalah pada pokok bahasan persamaan linear dua variable. 
Tabel 3. Hasil Uji Validitas Perangkat Pembelajaran

\begin{tabular}{clcc}
\hline No. & \multicolumn{1}{c}{ Lembar Validasi } & Rata-rataPenilaian & Kategori \\
\hline 1. & RPP & 3,16 & Valid \\
2. & Buku Peserta didik & 3,17 & Valid \\
3. & LKPD & 3,08 & Valid \\
4. & THB & 3,80 & Sangat Valid \\
\hline \multicolumn{2}{l}{ Rata-rataPenilaian Keseluruhan } & 3,30 & Valid \\
\hline
\end{tabular}

Tabel 3 menunjukkan bahwa perangkat pembelajaran yg dikembangkan memiliki nilai rata-rata 3,30 pada kategori valid karena setiap aspek untuk setiap jenis perangkat berada pada interval $2,5 \leq M \leq 3,5$ dan $3,5 \leq M \leq 4$ selain itu semua validator memberikan kesimpulan bahwa perangkat yang telah dikembangkan berada pada kategori baik dan dapat digunakan tanpa revisi.

Tabel 4. Hasil Uji Kepraktisan Perangkat Pembelajaran

\begin{tabular}{clcc}
\hline No. & Lembar Penilaian & Rata-rataPenilaian & Kategori \\
\hline 1. & Keterlaksanaan & 1,72 & Terlaksana \\
& Perangkat Pembelajaran & & Selruhnya \\
\hline
\end{tabular}

Tabel 4 menunjukkan rata-rata hasil penilaian keterlaksanaan perangkat pembelajaran matematika berbasis masalah adalah 1,72 berada pada kategori terlaksana seluruhnya (praktis) atau berada pada interval $1,5 \leq \bar{X} \leq 2$.

Tabel 5. Hasil Uji Keefektifan Perangkat Pembelajaran

\begin{tabular}{|c|c|c|c|}
\hline No. & Lembar Penilaian & Penilaian & Kategori \\
\hline \multirow[t]{3}{*}{1.} & THB & Hasil belajar peserta didik & \\
\hline & & tercapai karena $85 \%$ & Efektif \\
\hline & & $\begin{array}{l}\text { peserta didik mencapai } \\
\text { skor } 6,5 \text { ke atas. }\end{array}$ & \\
\hline \multirow[t]{3}{*}{2.} & Aktivitas Peserta Didik & Telah memenuhi kriteria & \\
\hline & & batas toleransi pencapaian & Efektif \\
\hline & & $\begin{array}{l}\text { waktu ideal yang } \\
\text { digunakan }\end{array}$ & \\
\hline \multirow[t]{2}{*}{3.} & Kemampuan Guru & Hasil rata-rata yang & \\
\hline & Mengelola Pembelajaran & $\begin{array}{l}\text { diperoleh yaitu } 3,4 \text { dari } \\
\text { skor idel } 4 \text { dan berada } \\
\text { pada kriteria tinggi dalam } \\
\text { interval } 3,5 \leq K G<4,5 \text {. }\end{array}$ & Efektif \\
\hline \multirow[t]{3}{*}{4.} & Angket Respon Peserta & Hasil respon peserta didik & \\
\hline & Didik & terhadap perangkat & \\
\hline & & pembelajaran & \\
\hline
\end{tabular}




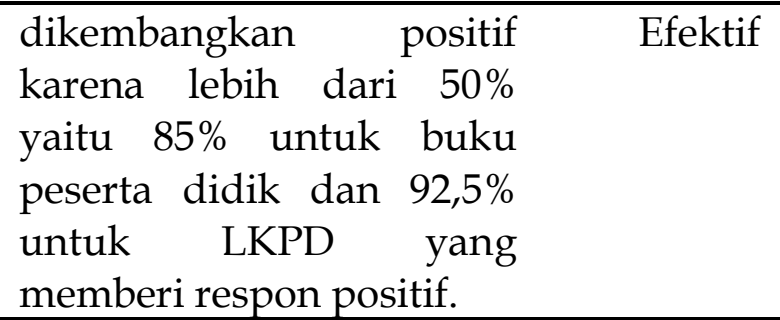

Dari keempat kriteria keefektifan yaitu, kemampuan guru mengelola pembelajaran, aktivitas peserta didik, respons peserta didik dan hasil belajar peserta didik, dapat disimpulkan bahwa pada tahap uji coba terbatas, perangkat pembelajaran matematika berbasis masalah telah memenuhi kriteria kevalidan, kepraktisan, dan keefektifan.

\section{SIMPULAN}

Berdasarkan hasil penelitian dan pembahasan dapat disimpulkan bahwa perangkat pembelajaran dikatakan layak jika telah memenuhi 3 syarat kelayakan yaitu valid, praktis, dan efektif. Ditinjau dari segi kevalidan, berdasarkan hasil validasi perangkat pembelajaran diperoleh data bahwa hasil validasi terbagi atas dua tahap yaitu tahap validasi I dan tahap validasi II. Pada tahap validasi I, semua perangkat pembelajaran dikatakan belum valid dan belum layak digunakan. Pada tahap II semua saran-saran para validator telah diperbaiki dan dikatakan valid serta layak digunakan. Berdasarkan hasil uji coba kepraktisan diperoleh bahwa hasil keterlaksanaan perangkat pembelajaran dinilai telah valid sehingga praktis untuk digunakan, berdasarkan data hasil uji coba keefektifan diperoleh data bahwa: (1) ratarata ketuntasan belajar peserta didik yang diperoleh adalah $85 \%$. (2) lima dari enam jenis aktivitas peserta didik yang diamati telah terpenuhi. (3) rata-rata skor kemampuan guru dalam pengelolaan pembelajaran adalah 3,4 dari skor ideal 4 (berada dalam kategori cukup/sedang), dan (4) dan hasil respons peserta didik terhadap pembelajaran positif dengan $85 \%$ peserta didik memberi respons positif terhadap buku peserta didik serta 92,5\% peserta didik memberi respons positif terhadap LKPD, sehingga dapat disimpulkan bahwa perangkat pembelajaran efektif untuk digunakan.

\section{DAFTAR PUSTAKA}

Abrar, A. I. P. (2016). Pembelajaran Berdasarkan Masalah Suatu Upaya untuk Mengembangkan Kemampuan Pemahaman dan Representasi Matematik Siswa. MaPan : Jurnal Matematika dan Pembelajaran, 4(1), 1-10.

Insani, K. F., Suharto, \& Indah, A. K. (2014). Pengembangan Perangkat Pembelajaran Matematika Berbasis Masalah (Problem Based Learning) untuk siswa SMP Kelas VIII Pada Pokok Bahasan sistem Persamaan Linear Dua Variabel (SPLDV). Kadikma, 5(3), 127-136.

Munawarah, M. (2017). Pengembangan Perangkat Pembelajaran Matematika dengan 
Menggunakan Pendekatan Kontekstual. MaPan: Jurnal Matematika dan Pembelajaran, 5(2), 168-186.

Nurhidayati, S., Tayeb, T., \& Abbas, B. (2017). Pengembangan Bahan Ajar Matematika

Berbasis Masalah untuk Memfasilitasi Pencapaian Kemampuan Penalaran Pada

Pokok Bahasan Perbandingan Kelas VII MTsN Model Makassar. MaPan: Jurnal Matematika dan Pembelajaran, 5(2), 236-250.

Siswono, D. (2008). Ilmu Pendidikan. Yogyakarta: UNY Press.

Sugiyono. (2012). Metode Penelitian Kuantitatif Kualitatif dan RED. Bandung: Alfabeta.

UU Sistem Pendidikan Nasional. (2011). Jakarta: Sinar Grafika.

Tatang, H. (2007). Pembelajaran Berbasis Masalah untuk Meningkatkan Kemampuan Berpikir Matematis Tingkat Tinggi Siswa Sekolah Menengah Pertama. Educationist, 1(1), 3. 